\title{
ENHANCING WORKFORCE COMPETITIVENESS THROUGH IMPROVING QUALITY OF EDUCATION - AN INDISPENSABLE MEANS FOR OVERCOMING POVERTY
}

\author{
Tea Kasradze Doctor of Economic Sciences, Professor, \\ Nino Zarnadze Doctor of Economic Sciences, Associate Professor \\ Tbilisi, Georgia, Caucasus International University
}

DOI: https://doi.org/10.31435/rsglobal_ijite/01062018/5654

\section{ARTICLE INFO}

Received 08 April 2018

Accepted 09 May 2018

Published 01 June 2018

\section{KEYWORDS}

Poverty,

unemployment,

education,

labour market,

competitive workforce

\begin{abstract}
Increasing globalisation and integration of economies entailed the rise of global problems as well. Today, the greater part of the planet is starving. The problems are aggravated by the advancement of scientific and technological progress which leaves the colossal part of human workforce beyond production process. It is impossible to overcome poverty without economic growth. However, economic growth does not affect poverty similarly in all countries. $1 \%$ growth of GDP reduces income poverty by $1 \%$ minimum and $4 \%$ maximum depending on the number of jobs created. It is possible to have economic growth in a country without creating a substantial number of jobs. Among many instruments of improving employment indicators and overcoming poverty we consider education to be the most crucial.
\end{abstract}

(C) 2018 The Authors.

Introduction. Increasing globalisation and integration of economies entailed the rise of global problems as well. There are problems the solution of which needs uniting world-wide efforts. There are four clusters of global problems, namely, political, economic, social and environmental. They are closely interrelated and it is often impossible and ineffective to solve each of them separately.

Today, the greater part of the planet is starving. The problems are aggravated by the advancement of scientific and technological progress which leaves the colossal part of human workforce beyond production process.

According to the UN data, almost half of the planet's population does not have access to sewerage and water supply system; 1 out of 3 does not have access to electricity; and 1 out of 5 does not have access to quality drinking water. In case of equal distribution of income, each inhabitant would be receiving the equivalent of 14 International Dollar, whereas almost 2.2 billion people live below the poverty line, receiving less than 2.5 International Dollar per day.

According to the UN statistics, 30,000 children are dying daily due to starvation and the lack of medical assistance. Millions of people still die annually because of famine, tuberculosis and other curable diseases.

In the modern world, poverty and backwardness are characteristic primarily of developing countries, where $2 / 3$ of the world population live. Accordingly, this problem is frequently referred to as the problem of overcoming backwardness of developing countries.

According to the data of Geostat, National Statistics Office of Georgia, the percentage of the population below the absolute poverty line went down from 46.7 to $32.3 \%$ in $2011-2014$. Since 2014, this indicator has decreased further by $7.6 \%$. However, in 2016, the indicator increased by $0.5 \%$ and amounted to $21.3 \%$. The number of the population that consumes less than $60 \%$ of average consumption of the overall population also increased by $0.5 \%$ and amounted to $20.6 \%$. The improvement is obvious but, if the indicator is compared to similar indicators of former Soviet countries (e.g. percentage of the Uzbek population below poverty line is $12.8 \% ; 4.9 \%$ in Azerbaijan; and $2.7 \%$ in Kazakhstan), it is evident that a great deal of effort is still required to overcome this huge challenge.

How to Overcome Poverty? Elaboration of an effective national strategy based on a complex approach is recognised as one of the crucial means of overcoming poverty and backwardness. The implementation of this strategy will pave for the establishment of a modern economy and ensure sustainable economic growth. It provides not only industrialisation of economic life but also liberalisation and transformation of agricultural relations, reformation of education and healthcare, 
respect for the rule of law, reduction of inequality, implementation of rational demographic policies and solution of unemployment problem.

To overcome poverty, the Government of Georgia carried out numerous activities. In 2006-2009, there was growth in every sector of the economy. The growth was in its turn reflected in salary increase and creation of jobs. Poverty reduction was noticeable in the rural areas too, which was directly linked with economic growth in the villages and in the agricultural sector. Furthermore, employment has increased in the rural areas in non-agricultural sectors as well (services, construction and industry).

In 2012-2014, social expenditure increased in actual indicators. Pensions, social and other direct transfers have increased. Accordingly, reallocation of budget funds contributed to reduction of inequality.

Despite the abovementioned progress, poverty problems remain unsolved. The reason is that onetime activities and distribution of income alone will not solve the problem of poverty. It is common knowledge that it is impossible to overcome poverty without economic growth. However, economic growth does not affect poverty similarly in all countries. $1 \%$ growth of GDP reduces income poverty by $1 \%$ minimum and $4 \%$ maximum depending on the number of jobs created. It is possible to have economic growth in a country without creating a substantial number of jobs. According to the data of the International Labour Organisation, there were 204 million unemployed individuals in 2015. Globally, from 2016 to 2030, 470 million jobs should be created for employment increased number of the fit to work population. It means that 30 million jobs should be created annually. ${ }^{1}$

In the last few years, many developing countries have had high indicators of economic growth; this, however, has not been reflecting greatly on poverty reduction and well-being of individuals.

All this leads to employment being indispensable for overcoming poverty. Among many instruments of improving employment indicators (creating jobs by the state, economic diplomacy, motivating small and large businesses by bank system and investors to create jobs, protectionism, liberalising tax system, developing the system of vocational training) we consider education to be the most crucial.

Education as an intellectual resource is the driving force of the modern society. It creates development potential and determines the ways to move forward. Intellectual resource is the set of education, skills and professional abilities that creates specific assets in the labour market.

Even though Georgia's Socio-Economic Development Strategy - Georgia 2020 acknowledges the need to have human resources trained in accordance with the labour market requirements and enhance research potential in the educational system, we believe that to this date harmonious functioning of the systems of education and employment has not been managed, whereas, educational system and labour market should be one system. In fact, they operate independently from each other's requirements. Accordingly, intellectual resources of job seekers and employers' expectations do not always coincide. This is confirmed by the fact that $81 \%$ of the unemployed has either secondary or higher education and $24 \%$ of those with higher education are jobless. This indicates the formal nature of education and incompatibility of qualifications with job requirements. The same is demonstrated by Georgia's low rating $\left(93^{\text {rd }}\right)$, according to the global competitiveness report of the World Economic Forum, in terms of education and training. It seems that the reforms carried out so far have been unable to solve the problem of employment in Georgia through improving the quality of education.

To eradicate problems in the educational system, it is required to identify the existing problems and search for the reasons causing them. Only after establishing these reasons will it be possible to reflect on the means of their eradication and to outline the ways of dealing with them.

We consider the following to be the reasons of the abovementioned problems:

1. The low quality of education and sometimes complete incompatibility with the market requirements. As a result, there are often jobs that remain vacant and an employer is forced to attract human resources from abroad. This worsens domestic unemployment. This problem is most noticeable in construction sector.

2. There are no clear criteria on the labour market concerning intellectual resources of job seekers. Often, job seekers technically meet job requirements; however, they lack relevant experience, practical skills and application of knowledge.

3. The way the labour market and educational system operate is not based on fundamental research of market. As a result, the overall picture is that the labour market requirements do not correspond with the final product of the educational system. The demand-supply curves do not cross each other, as if they operate in different dimensions.

\footnotetext{
${ }^{1}$ See at: http://www.un.org/ru/development/devagenda/pdf/Russian_Why_it_matters_Goal_8_Work\&Growth.pdf.
} 
4. The incompatibility of the educational system with the national plan of strategic development is due to the insufficient involvement of the state. For the development of the country, it is imperative to promote professions that would create new jobs in the long run. Considering the country's national plan, the educational system should already be planning instruction and training of the future generations.

5. The indicators of protectionism, lobbyism, nepotism and discrimination are high, especially in public sector. Most of the people are employed in public sector. Though there are clear recruitment procedures and competitions are announced, however, most of the resources are selected based on contacts rather than knowledge and experience.

Conclusions. The solution lies in enhancing the competitiveness of workforce by improving the quality of education. Improving the quality of education is a complex process encompassing all stages of educational process that requires time, money and efforts.

It is necessary to carry out frequent and comprehensive research of the labour market. The number of openings in educational programmes announced by universities should be based on the labour market requirements. More emphasis should be made on popularisation of priority jobs.

Vocational training needs to be promoted and popularised to a greater extent. By changing the stereotypes rooted in society and clearly demonstrating the benefits of vocational training, it is possible to prompt more youths to undergo vocational training instead of pursuing higher education and to adopt qualifications that would be more beneficial in terms of employment.

We hope that the new wave of reforms in the educational system, instituted in 2015, aimed at increasing trust in the Georgian educational system, internationalising and integrating it in the uniform European educational system through improving the quality of education will contribute to improving the employment indicator through supplying competitive workforce to labour market and will help the country to overcome poverty.

\section{REFERENCES}

1. Tea Kasradze, Poverty - Global Socio-Economic Problem, Journal "Caucasus International University Herald" \# 5, 2013

2. Bill Mitchell, The Best Way to Eradicate Poverty is to Create Jobs, available at http://bilbo.economicoutlook.net/blog/?p=16980

3. Influence of Higher Education on Workforce Formation, Research Report, The International Institute for Education, Policy, Planning and Management, Tbilisi, 2013

4. Education and Science Strategy of Georgia, 2013-2021

5. Social-Economic Strategy of Development of Georgia 2020 